\begin{tabular}{|c|c|c|}
\hline Beitr. Ent. & Keltern & ISSN 0005-805X \\
\hline $\mathbf{5 2}(2002) 2$ & S. $347-352$ & 16.12 .2002 \\
\hline
\end{tabular}

\title{
New data on chromosomes of sawflies in the families Argidae, Cimbicidae and Cephidae
}

\section{(Hymenoptera, Symphyta)}

With 7 figures and 1 table

\section{Magdalene WestendorfF and ANDREAS TAEger}

\section{Summary}

New data on chromosomes of cytogenetically little known sawfly families are presented. Five argid species (Arge gracilicornis, A. pagana, A. melanochra, A. cyanocrocea, and A. nigripes), Abia candens (Cimbicidac), and Calameuta filiformis (Cephidae) were karyotyped.

\section{Zusammenfassung}

Neue Ergebnisse der Chromosomenanalyse in zytogenetisch weitgehend unbekannten Blattwespenfamilien werden mitgeteilt. Die Karyotypen von fünf Arten der Argidae (Arge gracilicornis, A. pagana, A. melanochra, A. cyanocrocea und A. nigripes) sowie von Abia candens (Cimbicidae) und Calamenta filiformis (Cephidae) wurden untersucht.

\section{Keywords}

Karyotypes, Hymenoptera / Symphyta: Argidae, Cimbicidae, Cephidae

\section{Introduction}

The karyotypes of sawfly species in the families Argidae, Cephidae, and Cimbicidae are largely unknown. The Argidae is the second largest family of Symphyta and comprises some 800 species (SMITH, 1993). Only three of them have been studied cytogenetically (BENSON, 1950; MAXWELL, 1958). The haploid chromosome numbers of two of the 150 or more species of Cimbicidae (SMITH, 1993) have so far been reported (BENSON, 1950). In Cephidae with about 100 species known (SMTTH, 1993), karyotypes of two species have been published (MACKAY, 1955; CROZIER \& TASCHENBERG, 1972).

This study presents the first information about chromosomes of five argid species, Arge yyanocrocea, A. gracilicornis, A. melanochra, A. nigripes, and A. pagana, of the cimbicid, Abia candens, and of the cephid, Calamenta filiformis. 


\section{Material and methods}

Females and larvae were collected in Brandenburg and Thuringia (Germany) between 1996 and 1999. Information about species studied is given in the table. The systematic arrangement and nomenclature follow TAEGER \& BLANK (1998: 337-338). For chromosome analysis unfertilized eggs were incubated in vitro. To obtain haploid metaphase plates cerebral ganglia of 3-5 days old parthenogenetic male embryos were used (NAITO, 1971). Additionally, in Arge pagana diploid larvae collected in the field were studied. The chromosomes were prepared according to the method described by IMAI et al. (1977). The slides were stained with 5\% Giemsa. Observations and photos were made using the microscope BX 50 and the camera OM-4 (Olympus, Japan). For chromosome analysis chromosomes were classified in four groups: the two-armed metacentrics (M), submetacentrics (SM), and subtelocentrics (ST) and the one-armed acrocentrics (A) following LEVAN et al. (1964). The haploid arm number (NFn) was estimated on the basis that M, SM and ST display a value of two, while A a value of one. Chromosome preparations and remains of adult specimens have been deposited in the collection of the Deutsches Entomologisches Institut Eberswalde (ZALF e. V.)

Tab. 1: Karyotyped species

(n: haploid chromosome number; F- number of studied females, E- embryos of *Jarvae and M- metaphases)

\begin{tabular}{|c|c|c|c|c|c|c|}
\hline Family group & Species & $\mathrm{n}$ & $\mathrm{F}$ & $\mathrm{E}$ & $\mathrm{M}$ & Fig. \\
\hline $\begin{array}{l}\text { Tenthredinoidea } \\
\text { Argidae } \\
\text { Arginae }\end{array}$ & Arge gracilicomis (KuUG, 1814) & 8 & 2 & 6 & 75 & 1 \\
\hline & A. pagania (PANZER, 1798) & 8 & 1 & $\begin{array}{c}1 \\
2^{*}\end{array}$ & $\begin{array}{c}5 \\
20\end{array}$ & 2 \\
\hline & A. melanocbra (GMELIN, 1790) & 10 & 2 & 3 & 45 & 3 \\
\hline & A. yanocrocea (FORSTER, 1771) & 11 & 4 & 8 & 50 & 4 \\
\hline & A. nigripes (RETZIUS, 1783) & 13 & 1 & 2 & 65 & 5 \\
\hline $\begin{array}{l}\text { Cimbicidae } \\
\text { Abiinae }\end{array}$ & Abia candens KoNOW, 1887 & 16 & 2 & 5 & 80 & 6 \\
\hline $\begin{array}{l}\text { Cephoidea } \\
\text { Cephidae } \\
\text { Cephinae }\end{array}$ & Calameita filiformis (EvERSMLNN, 1847) & 20 & 2 & 5 & 8 & 7 \\
\hline
\end{tabular}




\section{Results and discussion}

Data on material including haploid chromosome numbers of the species and the number of studied females, embryos and metaphase plates are summarized in the table.

\section{Argidae}

In the five argid species studied two-armed metaphase chromosomes clearly predominate. A. gracilicornis, $\mathrm{n}=8(7 \mathrm{M}+1 \mathrm{ST}), \mathrm{NFn}=16$ and $A$. pagana, $\mathrm{n}=8(7 \mathrm{M}+1 \mathrm{M} / \mathrm{SM}), \mathrm{NFn}=16$ have similar karyotypes with mainly metacentrics and a large first chromosome (Fig. 1, 2). But they differ in the morphology of the seventh and eighth chromosomes. In $A$. gracilicornis these are $\mathrm{M}$ and ST whereas in the karyotype of $A$. pagana they are M/SM and M. A different karyotype was found in $A$. melanocbra with $\mathrm{n}=10(\mathrm{NFn}=20)$. The complement of $\mathrm{M}$ and SM is balanced, with $5 \mathrm{M}$ and $5 \mathrm{SM}$ (Fig. 3). The first large chromosomes are $\mathrm{M}$ and SM. The others gradually decrease in size. In $A$. cyanocrocea the karyotype displays 11 chromosomes ( $6 \mathrm{M}+5 \mathrm{SM}$; NFn=22). The set includes three large, two medium-sized and six small chromosomes (Fig. 4). The first five are SM whereas the others are M. In A. nigripes a karyotype with 13 chromosomes (Fig. 5) was found. There are two larger SM and ST in the set. The other chromosomes are smaller and the morphology can not be clearly determined for each. In some metaphases analysed it seems that one of the smaller chromosomes is an acrocentric.

Including the data from BENSON (1950) and MAXWELL (1958) eigth argid species have so far been karyotyped. BENSON reported a haploid chromosome number $\mathrm{n}=8$ for Arge ustulata without any further information on the karyotype (the reference was not given). MAXWELL (1958) studied the chromosomes of Arge clavicornis and A. pectoralis in primary spermatocytes. The karyotype of $A$. clavicornis includes 8 metacentrics. The first chromosome is relatively large, the others decrease gradually in size (MAXWELL, 1958: Fig. 71). Judging from the Fig. 70 in this study $A$. pectoralis has $n=7$ with gradual size seriation of chromosomes. This is inconsistent with the statement that: ,A. pectoralis and $A$. clavicornis in the family Argidae appear almost cytologically homogeneous " (MAXWELL, 1958). The argid haploid chromosome numbers range from $n=7$ to $n=13$. Four of eight species karyotyped have $n=8$. For two of them a similarity of karyotypes is evident (Fig. 1,2). The other four argid species differ markedly in number, size, and morphology of metaphase chromosomes. The prevalence of M and SM is a common character of analysed argid karyotypes.

\section{Cimbicidae}

In Abia candens the chromosome analysis revealed $n=16$ (Fig. 6). All chromosomes are small and it is difficult to judge the centromere position of each. The first two are SM, the others M/SM or ST/A.

Until now only two cimbicid species were karyotyped. Cimbex femoratus (cited as Cimbex femorata L.) and Trichiosoma lucorum have $n=8$ (BENSON, 1950). But BENSON did not describe the karyotypes in detail. A comparison between these known karyotypes and the 
newly studied complement of $A$. candens cannot be drawn. Considering only the chromosome numbers it can be concluded that $A$. candens has a very different karyotype with twice as many chromosomes as the other two cytogenetically studied cimbicid species. A tendency to an increasing number of ST/A with higher $\mathrm{n}$ was also observed by WESTENDORFF et. al. (1999) in some tenthredinid species (Hymenoptera: Tenthredinidae).
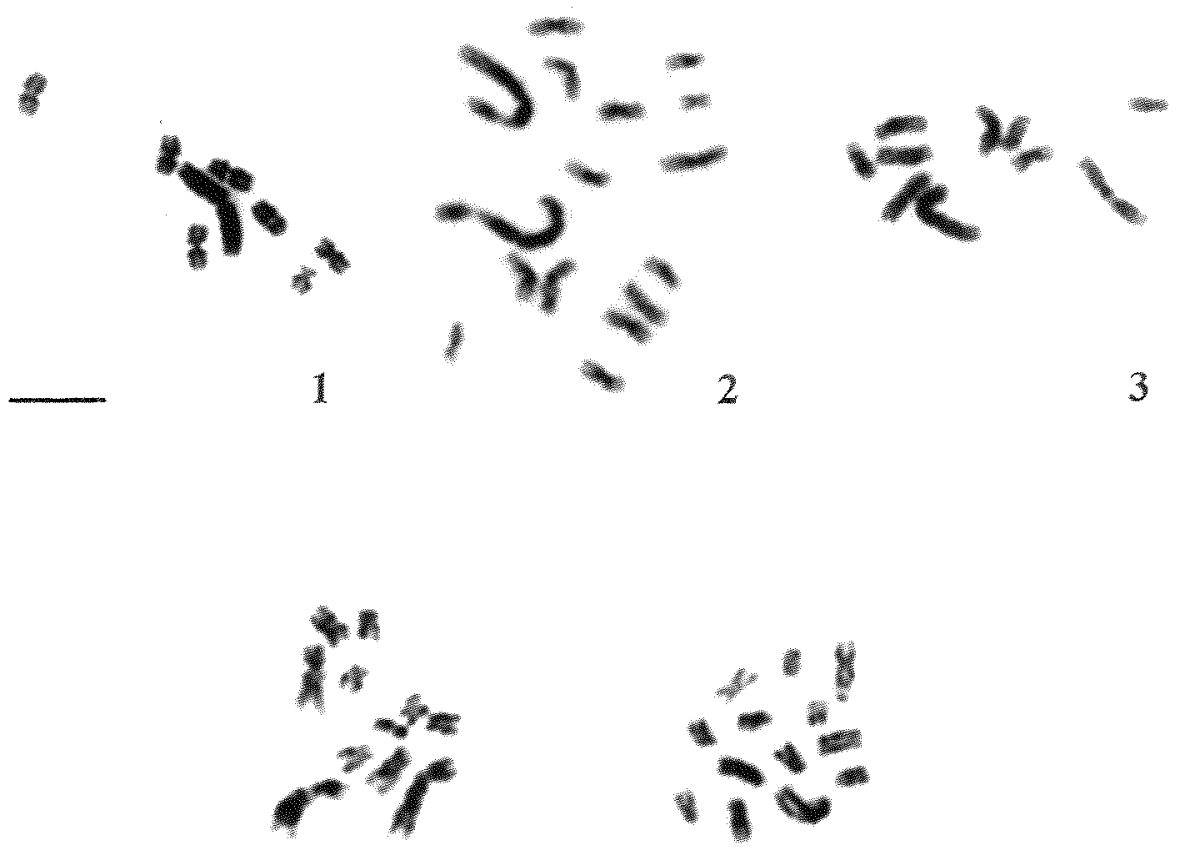

4

5
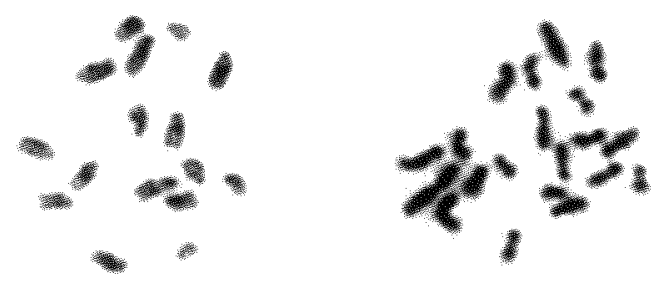

6

Figs. 1-7. Haploid (1,3-7) and diploid (2) metaphases: Arge gracilicornis (1); A. pagana (2); A. melanocbra (3); A. cyanocrocea (4); A. nigripes (5); Abia sandens (6); Calameuta filiformis (7). Bar equals $6,7 \mu \mathrm{m}$ in Fig. 1; $5 \mu \mathrm{m}$ in Figs. 2-5; $4,5 \mu \mathrm{m}$ in Fig. 6 and $3,9 \mu \mathrm{m}$ in Fig. 7 . 


\section{Cephidae}

The karyotype of Calameuta filiformis displays 20 chromosomes (Fig. 7) with a clear prevalence of two-armed elements. The first larger chromosome is a $\mathrm{M}$ and easily distinguishable. The identification of the morphology of the smaller chromosomes in the complement based on Giemsa staining is difficult.

Few data on other cephid species are available for comparison with this karyotype. The first karyotyped species in Cephidae was Cephus cinctus with $\mathrm{n}=9$ (MACKAY, 1955). In this karyotype three large and six small chromosomes were observed. All of them are metacentrics. As in Calameuta filiformis the smaller elements cannot be distinguished exactly one from another. The second species of Cephidae to be karyotyped was Janus integer (CROZIER \& TASCHENBERG, 1972). Eight male specimens were studied and karyotypes with $n=22,24,25$ and 26 found. This surprising result, unusual in sawflies, was attributed by the authors to polymorphism of the chromosome number. But judging from the photos published, the karyotypes show differences not only in the number but also in the morphology of chromosomes. The largest elements in the three presented karyotypes are $\mathrm{M} / \mathrm{SM}, \mathrm{ST}$, and $\mathrm{M}$ respectively. Although it is not possible to determine the centromere position of all chromosomes in the photos presented, there are further differences in the chromosome morphology. This seems to be true at least for the second, fifth and sixth elements. In sawfly cytology so far only SANDERSON (1970) reported different haploid chromosome numbers for Tentbredo brevicornis (cited as T. acerrima) with $\mathrm{n}=18-21$ (Hymenoptera: Tenthredinidae). T. brevicornis belongs to the T. arcuata-group where the species identification is uncertain in several aspects (TAEGER 1985). So the diversity of chromosome numbers for this species could be a result of karyotyping different species (cf. WESTENDORFF et al. 1999).

\section{Acknowledgements}

We gratefully acknowledge our colleagues of the Deutsches Entomologisches Institut, Eberswalde: S. M. BLANK and J. ZIEGLER for collecting some of the specimens studied and B. EWALD and CH. KUTZSCHER for technical assistance in this work. We thank A. D. LISTON (Frontenhausen), who kindly corrected the English.

\section{References}

BENSON, R. B. 1950: An introduction to the natural history of British sawflies (Hymenoptera, Symphyta). - Transactions of the Society for British Entomology 10: Part 2, 48-142.

CROzIER, R. H. \& TASCHENBERg, E. F. 1972: Chromosome number polymorphism in the sawfly Janus integer (Hymenoptera: Cephidae). - Psyche 79: 111-119.

IMAI, H. T.; CROZIER, R. H. \& TAYLOR, R. W. 1977: Karyotype evolution in Australian ants. - Chromosoma 59: 341-393.

LEVAN, A.; FREDGA, K. \& SANDBERG, A. 1964: Nomenclature for centromeric position on chromosomes. - Hereditas 52: 201-220.

MACKAY, M. R. 1955: Cytology and parthenogenesis of the Wheat Stem Sawfly Cepbus cinctus NORT. (Hymenoptera: Cephidae). - Canadian Journal of Zoology 33: 161-174.

MAXWELL, D. E. 1958: Sawfly Cytology with Emphasis upon the Diprionidae (Hymenoptera: Symphyta). Proceedings of the 10th International Congress of Entomology [1956] 2: 961-978. 
352 Westendorff, M. \& TAeger, A.: Chromosomes in the families Argidae, Cimbicidae, Cephidae

NAITO, T. 1971: A tevision of the genus Hemitaxonus in the Old world, II (Hymenoptera, Tenthredinidae). - Kontyû 39: 77-82.

SANDERSON, A. R. 1970: Further studies on the Cytology of Sawflies. - Proceedings of Royal Society, Edinburgh B61: 29-40.

SMITH, D. R. 1993: Systematics, Life History, and Distribution of Sawflies. pp. 3-32. - In: WAGNER, M. \& RAfFA, K. F. (Eds.): Sawfly Life History. Adaptations to Woody Plants. - San Diego, New York: Acad. Press, Inc. -581 pp.

TAEGER, A. 1985: Zur Systematik der Blattwespengattung Tenthredo (s. str.) L. (Hymenoptera, Symphyta, Tenthredinidae), - Entomologische Abhandlungen, Staatliches Museum für Tierkunde, Dresden 48: [1984] 83-148.

TAEgER, A. \& BlAnK, S. M. (Eds.) 1998: Pflanzenwespen Deutschlands (Hymenoptera, Symphyta). Verlag Goecke \& Evers, Keltern: 364 pp.

WestendorfF, M.; Kuznetsova, V. G.; TAEgER, A. \& Blank S. M. 1999: Karyotype Diversity in the Sawfly Family Tenthredinidae (Symphyta, Hymenoptera): New Data and Review. - Cytologia, Tokyo 64: 401-409.

\section{Author's addresses:}

Dr. MAgDalene WestendorfF and Dr. ANDREAS TAEGER

Deutsches Entomologisches Institut

im Zentrum für Agrarlandschafts- und

Landnutzungsforschung (ZALF)

Schicklerstraße 5

D-16225 Eberswalde

Deutschland

e-mail: westendorff@zalf.de, taeger@zalf.de 